\title{
INHIBITION ACTIVITY OF CLEOME SPECIES EXTRACT ON ONION GUEST ROOT
}

\author{
SUTTHIDUEAN CHUNHAKARN ${ }^{1 *}$, PRAKAIDAO YINGSANGA ${ }^{2}$, LADA MATHURASA ${ }^{3}$
}

${ }^{1}$ Programme in Chemistry, Faculty of Science and Technology, Phranakhon Rajabhat University, Bangkok, Thailand. ${ }^{2}$ Programme in Agricultural Management Technology, Faculty of Science and Technology, Phranakhon Rajabhat University, Bangkok, Thailand. ${ }^{3}$ Programme in Environmental Science and Technology, Faculty of Science and Technology, Phranakhon Rajabhat University, Bangkok, Thailand. Email: sugar_sea@hotmail.com

Received: 16 February 2019, Revised and Accepted: 13 March 2019

\section{ABSTRACT}

Objective: Biological control is useful in agricultural. Allelopathy plays an important factor in crop productivity. The effect of allelopathy is able to produce and release allelochemicals or phytochemicals to inhibit or stimulate seed germination, seeding growth, shoot and root growth of other crops. The aim of this study was to evaluate the inhibitory activity of Cleome viscose and Cleome spinosa extracts on onion guest roots length.

Methods: The whole plants of C. viscose and C. spinosa were extracted with dichloromethane, ethyl acetate, methanol and distilled water, respectively. Each group of onion guests was sprayed at various concentrations as 100, 200, 400, 800 and 1600 parts per million for the treatment. The root growth was measured every day for 1 month.

Results: At concentration of 1600 ppm, methanol crude extract of C. spinose showed the highest percent inhibitory activity value of 91.68 . Ethyl acetate and methanol crude extracts of C. viscose showed strong inhibitory activity with percentage values of 90.17 and 90.90 , respectively, at concentration of 1600 ppm. Moreover, the methanol extract of C. viscose and C. spinosa evaluated higher inhibitory activity than other solvent. However, distilled water crude extract of C. spinose showed weak inhibitory activity with the percentage value of 40.05 at concentration of 1600 ppm.

Conclusions: In this study, the methanol crude extract of C. spinose showed potent inhibitory activity on root growth. Moreover, ethyl acetate and methanol crude extracts of $\mathrm{C}$. viscose evaluated strong inhibitory activity. C. viscose and C. spinosa extracts possessed allelochemicals for postharvest biology and technology in plants.

Keywords: Cleome viscosa, Cleome spinosa, Onion guests, Inhibitory activity.

(c) 2019 The Authors. Published by Innovare Academic Sciences Pvt Ltd.This is an open accessarticle under theCC BY license (http://creativecommons. org/licenses/by/4. 0/) DOI: http://dx.doi.org/10.22159/ijap.2019.v11s3.M0007

\section{INTRODUCTION}

Agricultural products have produced for the requirement of population. Thus, irradiation technology and agrochemicals such as fertilizers, herbicides, liming and acidifying agents, and pesticides have used to produce crop yields [1,2]. Nowadays, biological control is one of an alternative to use in agricultural. Allelopathy plays an important factor in crop productivity. The effect of allelopathy is able to produce and release allelochemicals or phytochemicals to inhibit or stimulate seed germination, seeding growth, shoot, and root growth of other crops [3-5].

Onion guest (Allium cepa L.), belongs to the family Alliaceae, is an industrial crop of the tropical. Onion guest is grown for food ingredients. They are mostly valued for aroma flavor and nutritional as minerals and trace elements [6,7]. One method of the postharvest cultivar is gamma-irradiated [8]. It is the most popular method but the root length of an onion guest is grown. This problem results in low cost in the market.

Cleome viscosa and Cleome spinosa belong to the family Capparidaceae. It is a common weed and distributes in the tropical of the world. This plant possesses Ayurveda medicine such as seed used for anthelmintic, leaves used in wound healing, and fever $[9,10]$. Moreover, pharmacological of this plant is evaluated as an anesthetic, anti-diarrhea, anti-inflammatory, antimalarial, and antipyretic activities [11-13]. Moreover, the phytotoxic activity of C. viscosa showed inhibitory effect on germination and growth in agricultural product [14]. The aim of this research was to evaluate the inhibitory activity of $C$. viscosa and $C$. spinosa extracts on onion guest roots length.

\section{MATERIALS AND METHODS}

Plant materials

A. сера L. was purchased from the local market (Si Mum Mueang Market), Pathum Thani Province, Thailand, in January 2018. The whole plants of $C$. viscosa and $C$. spinosa were collected from the wilderness, Don Mueang, Bangkok Province, Thailand.

\section{Chemicals}

All solvents were analytical grade. Dichloromethane, ethyl acetate, and methanol were purchased from E. Merck (Germany). Absolute ethanol was purchased from E. Merck (Germany).

\section{Preparation of plant extract}

The whole plants of $C$. viscosa and $C$. spinosa were dried in the oven at $60^{\circ} \mathrm{C}$. Then, there were powdered by a mechanical grinder. The sample $(5.0 \mathrm{~kg})$ was extracted with dichloromethane for 3 days. Then, the extract was filtered and evaporated by the rotary evaporator to afford yellow gum (dichloromethane extract). The residue was extracted with ethyl acetate for 3 days. Then, the extract was filtered and evaporated by rotary evaporator to afford green gum (ethyl acetate extract). Finally, the residue was extracted with methanol for 3 days. The filtrate was evaporated by rotary evaporator to afford brown gum (methanol extract). The dried plant was extracted with distilled water at $40^{\circ} \mathrm{C}$ for 3 days. Then, the extract was filtered and evaporated by the rotary evaporator to afford brown gum (methanol extract).

\section{Inhibitory activity of the extract on root length}

Each of 20 onion guests was collected in the group of experimental. The concentrations of crude extracts were prepared at 100, 200, 400, 800, and $1600 \mathrm{ppm}$ in $20 \% \mathrm{v} / \mathrm{v}$ ethanol in water for the treatment. The different 


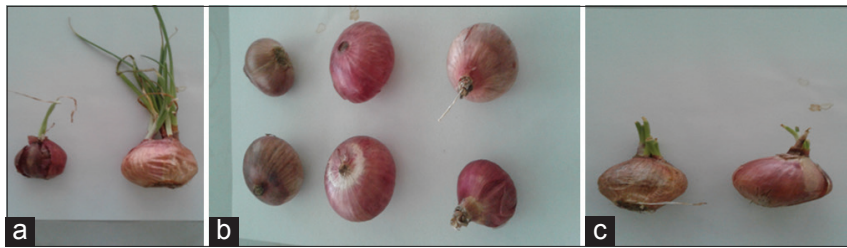

Fig. 1: Inhibitory activity of Cleome viscosa on roots length, (a) untreated control, (b) ethyl acetate extract at $1600 \mathrm{ppm}$, (c) negative control

Table 1: Inhibitory activity of $C$. viscosa and $C$. spinosa on roots length of onion guest

\begin{tabular}{llllll}
\hline \multirow{2}{*}{ Extract } & \multicolumn{6}{l}{ Concentration of extract (ppm) } \\
\cline { 2 - 6 } & $\mathbf{1 0 0}$ & $\mathbf{2 0 0}$ & $\mathbf{4 0 0}$ & $\mathbf{8 0 0}$ & $\mathbf{1 6 0 0}$ \\
\hline Dichloromethane (DS) & $27.52^{\mathrm{a}}$ & $39.15^{\mathrm{a}}$ & $50.26^{\mathrm{b}}$ & $51.85^{\mathrm{b}}$ & $63.20^{\mathrm{b}}$ \\
Ethyl acetate (ES) & $12.98^{\mathrm{a}}$ & $23.46^{\mathrm{a}}$ & $51.23^{\mathrm{b}}$ & $52.31^{\mathrm{b}}$ & $83.21^{\mathrm{c}}$ \\
Methanol (MS) & 20.25 & 24.02 & 43.66 & 48.29 & 91.68 \\
Distilled water (WS) & $10.03^{\mathrm{a}}$ & $10.01^{\mathrm{a}}$ & $10.51^{\mathrm{a}}$ & $11.01^{\mathrm{a}}$ & $40.05^{\mathrm{b}}$ \\
Dichloromethane (DV) & $12.59^{\mathrm{a}}$ & $13.35^{\mathrm{a}}$ & $35.46^{\mathrm{b}}$ & $50.17^{\mathrm{c}}$ & $53.21^{\mathrm{c}}$ \\
Ethyl acetate (EV) & $20.10^{\mathrm{a}}$ & $22.10^{\mathrm{a}}$ & $40.17^{\mathrm{b}}$ & $71.30^{\mathrm{c}}$ & $90.17^{\mathrm{c}}$ \\
Methanol (MV) & $18.61^{\mathrm{a}}$ & $20.50^{\mathrm{a}}$ & $50.30^{\mathrm{b}}$ & $51.25^{\mathrm{b}}$ & $90.90^{\mathrm{c}}$ \\
Distilled water (WV) & $17.02^{\mathrm{a}}$ & $29.04^{\mathrm{a}}$ & $45.30^{\mathrm{b}}$ & $52.34^{\mathrm{b}}$ & $56.78^{\mathrm{b}}$ \\
Negative control & $0.33^{\mathrm{a}}$ & $0.36^{\mathrm{a}}$ & $0.31^{\mathrm{a}}$ & $0.32^{\mathrm{a}}$ & $0.39^{\mathrm{a}}$ \\
Untreated control & $0.01^{\mathrm{c}}$ & $0.05^{\mathrm{b}}$ & $0.05^{\mathrm{b}}$ & $0.01^{\mathrm{c}}$ & $0.01^{\mathrm{c}}$ \\
\hline
\end{tabular}

C. viscosa: Cleome viscosa, C. spinosa: Cleome spinosa Values with different letters in a column show significant differences $(P<0.01)$ as determined by Duncan's multiple range test.

concentrations of crude extract sprayed to the group of treatments. The root growth was measured every day for 1 month. An untreated control and negative control (20\% ethanol in water) were compared with the experimental. Inhibitory activity (\%) was calculated from the equation below.

Inhibitory activity $(\%)=\left(\frac{1-\text { Root length of sample }}{\text { Root length of control }}\right) \times 100$

\section{Statistical analysis}

The experiment was designed by a randomized complete block design. Results were recorded using analysis of variance (Duncan's new multiple range tests). The significant value of $\mathrm{p}<0.01$ was considered.

\section{RESULTS AND DISCUSSION}

Observation of roots length measured on onion guest is presented in Table 1 and Fig. 1. Methanol, ethyl acetate, and MV crude extracts at $1600 \mathrm{ppm}$ showed the highest percent inhibitory activity values of 91.68 , 90.17, and 90.90, respectively. While, dichloromethane and distilled water crude extracts of C. viscose displayed weak inhibitory activity with percentage values of 53.21 and 56.78 , respectively, at concentration of $1600 \mathrm{ppm}$. The concentration of WS crude extract showed no different significant inhibitory activity. The methanol extract of $C$. viscosa and $C$. spinosa evaluated higher inhibitory activity than other solvent.

Ethyl acetate and methanol crude extracts of $C$. viscosa and C. spinosa possessed an inhibition activity on the root length of onion guest after postharvest that compared negative and untreated controls. The percentage inhibition activity depended on the concentration and type of solvents. When the increased concentration of the extract results in the percentages, inhibitory activity was raised. Aloe vera gel extracts reduced root length of onion root tip [15]. In contrast, water extract of C. viscosa showed inhibition of roots of Sesamum indicum [16].
Moreover, the methanol extract of $C$. arabica inhibited root length of lettuce and isolated active compounds from this plant [14]. However, licorice and seaweed extract increased onion production $[17,18]$.

\section{CONCLUSION}

In this research, C. viscosa and C. spinosa extracts inhibited root length of onion guest. The research is further to be isolate and purify allelochemicals of $C$. viscosa and $C$. spinosa.

\section{ACKNOWLEDGMENT}

This work was supported by grants from Phranakhon Rajabhat University. The authors would like to appreciate Phranakhon Rajabhat University for providing financial support to this research.

\section{CONFLICTS OF INTEREST STATEMENT}

We declare that we have no conflicts of interest.

\section{REFERENCES}

1. Maharjan S, Shrestha BB, Jha PK. Allelopathic effects of aqueous extract of leaves of Parthenium hysterophorus L. seed germination and seedling growth of three cereal crops of some cultivated and wild herbaceous species. Sci World 2007;5:33-9.

2. Han CM, Pan KW, Wu N, Wang JC, Li W. Allelopathic effect of ginger on seed germination and seedling growth of soybean and chive. Sci Hortic 2008;116:330-6.

3. Ali HH, Tanveer A, Nadeem MA, Javaid MM, Kashif MS, Chadhar AR. Allelopathic effects of Rhynchosia capitata on germination and seeding growth of Mungbean. Planta Daninha 2013;31:501-9.

4. Arowosegbe S, Wintola OA, Afolayan AJ. Phytochemical constituents and allelopathic effect of Aloe ferox Mill. Root extract on tomato. J Med Plants Res 2012;6:2094-9.

5. Amb MK, Ahluwalia AS. Allelopathy: Potential role to achieve new milestones in rice cultivation. Rice Sci 2016;23:165-83.

6. Yousaf Z, Umer A, Younas A, Khan F, Wang Y. Allelopathic Plants: 24. Genus Allium L. Allelopathy J 2012;29:1-12.

7. Wang Y, Tian WX, Ma XF. Inhibitory effects of onion (Allium cepa L.) extract on proliferation of cancer cells and adipocytes via inhibiting fatty acid synthase. Asian Pac J Cancer Prev 2012;13:5573-9.

8. Vaijapurkar SG, Agarwal D, Chaudhuri SK, Senwar KR, Bhatnagar PK. Gamma-irradiated onions as a biological indicator of radiation dose. Radiat Meas 2001;33:833-6.

9. Devi BP, Boominathan R, Mandal SC. Evaluation of antipyretic potential of Cleome viscosa Linn. (Capparidaceae) extract in rats. J Ethnopharmacol 2003;87:11-3.

10. Sungh H, Ali SS, Khun NA, Mishra KA, Mushra AK. Wound healing potential of Cleome viscosa Linn. seeds extract and isolation of active constituent. S Afr J Bot 2017;112:460-5.

11. Parimala D, Boominathan R, Mandal SC. Evaluation of anti-diarrheal activity of Cleome viscosa L. extract in rats B. Phytomedicine 2002;9:739-42.

12. Bose U, Bala V, Ghosh TN, Gunasekaran K, Rahman AA. Antinociceptive, cytotoxic and antibacterial activities of Cleome viscosa leaves. Rev Bras Farmacogn 2011;21:165-9.

13. Mali RG, Mahajan SG, Mehta AA. In vitro screening of Cleome viscosa extract for anthelmintic activity. Pharm Biol 2007;45:766-8.

14. Ladhari A, Omezzine F, Greca MD, Zarrelli A, Zuppolini S, Haouala R. Phytotoxic activity of Cleome arabica L. and its principal discovered active compounds. S Afr J Bot 2013;88:341-51.

15. İlbaş Aİ, Gönen U, Yilmaz S, Dadandi MY. Cytotoxicity of Aloe vera gel extracts on Allium cepa root tip cells. Turk J Bot 2012;36:263-8.

16. Anbarasan R, Prabhakaran J. Allelopathic potential of weed species Ageratum conyzoides L. and Cleome viscose L. on germination and growth of Sesamum indicum L. Kong Res J 2015;2:114-7.

17. Babilie R, Jbour M, Trabi BA. Effect of foliar spraying with licorice root and seaweed extraction growth and seed production of onion (Allium cepa L.). Int J Chem Tech Res 2015;8:557-63.

18. Dogra BS, Mandradia RK. Effect of seaweed extract on growth and yield of onion. Int J Farm Sci 2012;2:59-64. 